\title{
The Influence of Service Quality and Price on the Interest of Commuterline KRL Passengers
}

\author{
Waode Utari Nur Aisyah ${ }^{1}$, Fahruddin Salim ${ }^{2}$, Mohammad Sofyan ${ }^{3}$ \\ ${ }^{1}$ Marketing Management Ibn Chaldun University, Jakarta \\ ${ }^{2}$ Faculty of Economics, Pancasila University, Jakarta \\ ${ }^{3}$ Institute of Social Sciences and Management STIAMI, Jakarta
}

Correspondence: waode.utariii@gmail.com

Submitted: 1 August 2019. Revised: 28 August, 15 Sept 2019. Published: 30 October 2019.

\begin{abstract}
This electric train transportation facility is a means of transportation that avoids traffic congestion because it has its own route. Transportation competition can be seen through aspects of service quality to transportation service providers. The excellence of the company can be demonstrated by providing good quality service and striving for affordable ticket prices by the public. This study aims to determine and analyze the effect of Service Quality and Prices on Commuterline KRL Passenger Interest. This study used 125 respondents who used the commuterline train at Tanjung Priok station. This study used a quantitative method with multiple linear regression analysis taking data by distributing questionnaires. Sampling in this study using nonprobability sampling techniques. The results of the analysis partially and simultaneously show that service quality and price affect the interests of passengers.
\end{abstract}

Keywords: Service Quality, Price, and Passenger Interest

\section{INTRODUCTION}

Transportation is a means for humans to move things, both humans or objects from one place to another, with or without using tools. Transportation serves to overcome the gap in distance and communication between the place of origin and destination.

One of the means of transportation is electric trains, this transportation is a means of transportation that avoids congestion because it has its own route. As one of the largest mass transportation companies in Indonesia, Electric Train (KRL) has great potential to become a solution for increasingly complex urban transportation problems. But to be able to realize this, as a manager, PT. KAI Commuter Indonesia (KCI) still needs to increase the number of units and the quality of existing KRL services to achieve passenger satisfaction.

Indonesian commuterline trains began modernizing KRL transport in 2011 by simplifying existing routes into five main routes, eliminating express KRL, implementing special female trains, and changing the name of economy-AC KRL to Commuterline trains. The project will continue with the renovation, rearrangement and sterilization of facilities and infrastructure, including the railroad and train stations, which will be carried out with PT KAI (Persero) and the Government. There has been a phenomenal development in the mobility of people and goods in the country. This development encourages higher public demand for the quality and quantity of public transportation services (Rajeswari \& Santa Kumari, 2014). The purpose of implementing a new online ticketing system or the so-called Rail Ticketing System is expected to further accelerate services and make it easier for train transportation service users to get tickets (Septianita, Agus Winarno, \& Arif, 2014). The use of E-Ticketing is a form of support from companies that can play 
The Influence of Service Quality and Price on the Interest of Commuterline KRL Passengers at Tanjung Priok Station Aisyah, Salim, Sofyan

an important role in increasing competitive advantage in terms of customer loyalty (Setiawan, 2015).

This shows that the demand of people in developed countries for rail transportation services is still very high, so the railroad industry must be considered for its existence in a country, especially a country with a dense population. Transportation of people and goods transport mainly on the islands of Java and Sumatra. The train is a mass carrier with high capacity is an ideal means of transportation. However, the attention of the government in facilitating railway facilities and infrastructure is still not optimal.

KCI has been trying to spread widely, recently the Tanjung Priok large station has been reoperated not to reduce the likelihood of people using private vehicles so as to slightly reduce traffic congestion in Jakarta.

PT. KCI, under the auspices of the railroad, must have paid attention to the location, business strategy, and the quality of services it has in its company to reduce congestion in the capital, but it has not been seen as significant due to the large population. Based on the above understanding of the quality of service, the price of the passenger volume at each station is a factor concerned with each other.

The role of trains in Indonesia is still very marginal. In terms of transportation market share, trains for passenger transport are only $7.3 \%$ and goods transport is approximately $0.6 \%$. However, especially for economy class passengers, it is still often overloaded, especially when approaching Idul Fitri. As a result, passengers do not feel comfortable when using train services. Customers are satisfied if they can ride the train at a low cost, even without enjoying the trip (Semuel \& Wijaya, 2010).

Guidance in the field of traffic and railroad transportation which covers aspects of regulation, control and supervision of traffic is carried out by prioritizing and paying attention to the service of the public interest or the community of railroad service users, environmental sustainability, spatial planning, development of science and technology. The development carried out by the government is also intended to create safe, secure, fast, smooth, orderly and orderly railroad traffic and is integrated with other modes of transportation.

In order to fulfill the interests of the government as trainers and train transportation and meet the interests of the community of railroad service users, this is manifested in various provisions in this Government Regulation, among others, concerning rail service networks, railroad operations, transportation of people and goods by train, tariff structure and class. People more often use private vehicles because of several factors that make people not use public transportation. The quality of service of station officials and prices that are still unknown by ordinary people make the congestion of the capital city that is still difficult for the government to overcome. Because the quality of service is questionable the railroad is trying to improve its core area and provide quality service to passengers. The efforts of the railroad section will definitely retain passengers in enjoying their services in the future.

The result indicates that a larger gap has been found in Reliability and Assurance dimensions of Railway service quality and the most important factors determining satisfaction of passengers are basic facilities, safety \& security, punctuality and employee behavior towards passengers. It was found that the dimensions that influence the good services were Reliability and Assurance (Hundal \& Kumar, 2015). Using SERVQUAL methodology, the optimal fuzzy interval of gap scores is determined for each item. Fuzzy approach is a more realistic way to use linguistic assessments instead of numerical values. An empirical study is conducted using the proposed approach 
The Influence of Service Quality and Price on the Interest of Commuterline KRL Passengers at Tanjung Priok Station Aisyah, Salim, Sofyan

(Maruvada \& Bellamkonda, 2010). The results indicate gaps in two of the five dimensions and 15 attributes were ascertained to have influenced perception of service quality leading to customer dissatisfaction (Ojo, Mireku, Suleman, \& Nutsogbodo, 2014)

\section{METHOD}

The methodology used in this study includes research design, sampling techniques, and data collection and analysis tools (Kalaiselvi, Sandhya, \& Athira, 2017). This study aims to obtain proof of a causal relationship between the independent variables consisting of service quality and price with the dependent variable, namely the interest of commuterline crews at Tanjung Priok station.

Population is the total number of subjects to be studied by a researcher. In terms of population understanding, all variables are related to the topic of research. In this study, the population is passengers who take the train and get off at Tanjung Priok station.

The sample is a portion of subjects taken from the whole research subject (population). This partial amount will be the focus of research. Of course the sum of the part drawn (sample) must represent the entire number of research subjects (population). In other words Population and Sample are two things that are interrelated or inseparable.

According to Hair et al in Setyo stated that the minimum number of samples is 5 times the number of question items contained in the questionnaire (Setyo, 2017). The indicators in this study consisted of 2 independent variables and 1 dependent variable. Total questions in this study were 21 statements, so that the minimum sample size of this study was $21 \times 5=105$

Table 1. Definition of Variable Operations

\begin{tabular}{|c|c|c|c|}
\hline No & $\begin{array}{l}\text { Variable } \\
\text { Name }\end{array}$ & Dimension & Indicator \\
\hline \multirow[t]{9}{*}{1} & \multirow[t]{9}{*}{ Service quality } & Tangible & Neat and professional appearance \\
\hline & & \multirow[t]{2}{*}{ Reliability } & Clarity of information given in the schedule \\
\hline & & & Clarity of schedule given at the station \\
\hline & & \multirow[t]{2}{*}{ Responsiveness } & Modern appearance - station \\
\hline & & & Providing train services on time \\
\hline & & \multirow[t]{2}{*}{ Assurance } & Staff availability in handling your requests \\
\hline & & & Be informed if there is a delay \\
\hline & & \multirow[t]{2}{*}{ Empathy } & Have the knowledge to answer your questions \\
\hline & & & $\begin{array}{l}\text { Deal with you in a thoughtful manner when you } \\
\text { ask questions }\end{array}$ \\
\hline \multirow[t]{3}{*}{2} & \multirow[t]{3}{*}{ Price } & Cost oriented pricing & Affordability of prices \\
\hline & & $\begin{array}{l}\text { Demand oriented } \\
\text { pricing }\end{array}$ & Price competitiveness \\
\hline & & $\begin{array}{l}\text { Competition oriented } \\
\text { pricing }\end{array}$ & Price match \\
\hline \multirow[t]{4}{*}{3} & \multirow[t]{4}{*}{$\begin{array}{l}\text { Passenger } \\
\text { Interest }\end{array}$} & \multirow[t]{4}{*}{ Passenger Interest } & $\begin{array}{l}\text { Consumers have the desire to use commuterline } \\
\text { train services }\end{array}$ \\
\hline & & & $\begin{array}{l}\text { Consumers have the desire to buy a product to } \\
\text { meet their needs }\end{array}$ \\
\hline & & & $\begin{array}{l}\text { Consumers tell friends after feeling comfortable in } \\
\text { commuterline train services }\end{array}$ \\
\hline & & & $\begin{array}{l}\text { Consumers recommend to family and friends to } \\
\text { use commuterline train transportation services. }\end{array}$ \\
\hline
\end{tabular}


The Influence of Service Quality and Price on the Interest of Commuterline KRL Passengers at Tanjung Priok Station Aisyah, Salim, Sofyan

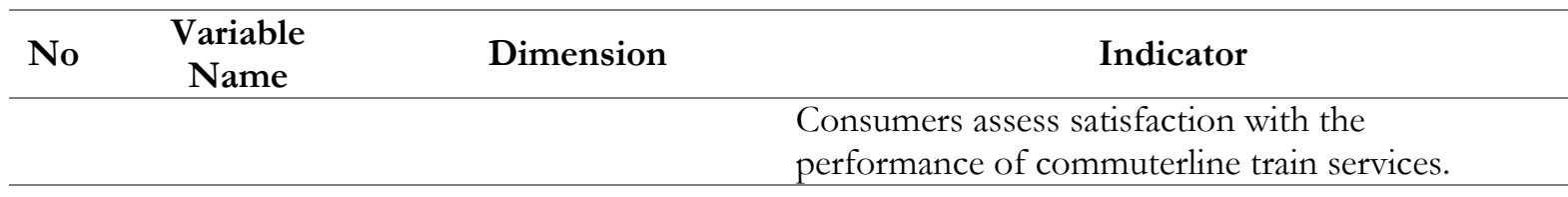

\section{RESULT AND DISCUSSION}

Table 2. F- test results

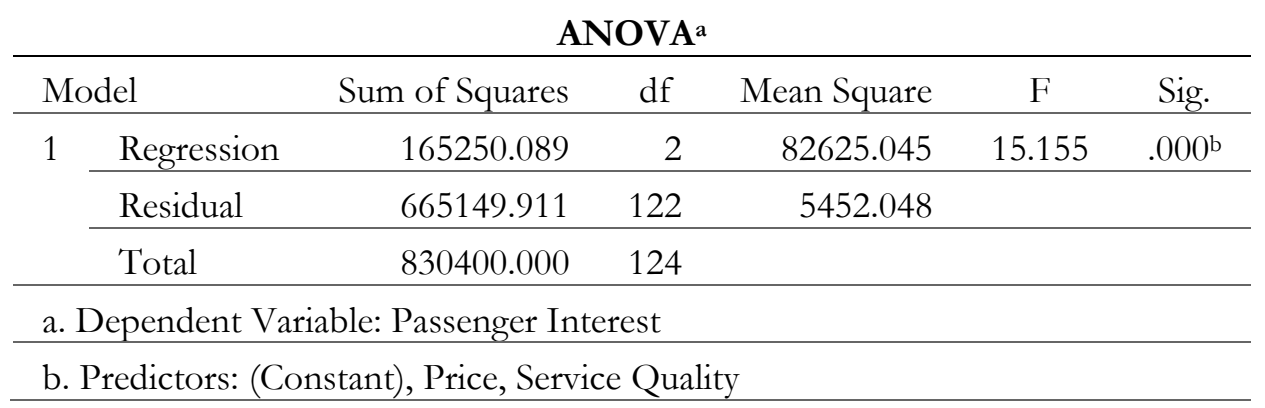

The results of the calculation above there is the $F_{\text {value }}$ is 15,155 and the $F_{\text {table }}$ can be searched from the $F$ table with a significance level of $5 \%$ or 0.05 using the formula $F_{\text {table }}=(\mathrm{k}$; nk), where $K$ is the number of independent variables, while $\mathrm{N}$ is the number of respondents. Then produces the number $(2 ; 125-2)=(2 ; 123)$, so for it $F_{\text {table }} 3.07$. Because $F_{\text {value }} 15.155>$ from $F_{\text {table }} 3.07$ can be concluded that $\mathrm{H}_{a}$ accepted $\mathrm{H}_{0}$ rejected, That means that service quality and price simultaneously influence the interest of commuterline KRL at Tanjung Priok station.

Table 2. T- test results

\begin{tabular}{lllll}
\hline No & Variable name & T Count & T Table & Decision \\
\hline $\mathbf{1}$ & Service Quality & 4.723 & 1.979 & Take effect \\
\hline $\mathbf{2}$ & Price & -3.238 & -1.979 & Take effect
\end{tabular}

\section{Effect of Service Quality on Passenger Interest}

The results of this study indicate that the service quality variable has a positive and significant effect on the interests of commuterline train passengers at Tanjung Priok Station. With the results obtained in the t-test of 4.723 and sig $0.000<\mathrm{a}=0.05$. This can be interpreted that a good quality of service will increase the interest of commuterline KRL passengers at Tanjung Priok station.

Quality of service is an absolute thing that must be owned by a company or agency that offers services, because with the quality of service to consumers, companies or agencies can measure the level of performance that has been achieved.

\section{Effect of Prices on Passenger Interest}

The results of this study indicate that the variable price has a negative and significant effect on the interests of commuterline train passengers at Tanjung Priok Station. With the results obtained in the t-test of -3.238 and sig $0.002<\mathrm{a}=0.05$. This can be interpreted that the increase 
The Influence of Service Quality and Price on the Interest of Commuterline KRL Passengers at Tanjung Priok Station Aisyah, Salim, Sofyan

in train ticket prices affects the interest of commuterline KRL passengers at Tanjung Priok station. In this case price affordability, price competitiveness, price suitability, generate interest from commuterline KRL passengers especially at Tanjung Priok station. In an effort to increase purchasing interest, prices also play a role in influencing consumer interest in a product (Aptaguna \& Pitaloka, 2016).

\section{Effect of Service Quality and Prices on Passenger Interest}

The results of this study indicate that the F-test results with a $f_{\text {value }}$ of 15,155 values are greater than $F_{\text {table }} 3.07$ atau $f_{\text {value }} 15.155>f_{\text {table }} 3.07$ with a probability of 0,000 . Because the probability value is much smaller than 0.05 , the quality of service and price together (simultaneously) affect the interests of passengers. This was felt at PT. KCI that service quality and price affect passenger interest.

\section{CONCLUSION}

Service quality has a positive and significant effect on the interest of commuterline KRL passengers at Tanjung Priok station. Ticket prices have a negative and significant effect on the interest of commuterline KRL passengers at Tanjung Priok station. Quality of service and price simultaneously have a significant effect on the interest of commuterline KRL passengers at Tanjung Priok station.

Based on the results of the coefficient of determination $\mathrm{R}_{\text {square }}$ of $19.9 \%$ which means that the variable service quality and price can explain the variable interest of commuterline KRL passengers at Tanjung Priok station indicating there are still other variables of $80.1 \%$ which must be considered in this study. In the quality of services, clear train information needs to be improved if there are delays and provide train services on time. Passengers prioritize the existence of good service for their convenience, although ticket prices are still considered to be competing with other transportation such as the Transjakarta busway but it does not affect the interest of passengers to take the commuterline KRL based on ticket prices. Further studies, should add other variables that can affect passenger interest. Therefore, with the better quality of service from employees and station staff, it will also have a good effect on government agencies or companies.

\section{REFERENCE}

Aptaguna, A., \& Pitaloka, E. (2016). Pengaruh Kualitas Layanan Dan Harga Terhadap Minat Beli Jasa Go-Jek. Widyakala, 3, 49-56. Retrieved from https://www.upj.ac.id/userfiles/files/Widyakala Vol 3 pp 49-56 (Aptaguna_Oka).pdf

Hundal, B. S., \& Kumar, V. (2015). Assessing the service quality of Northern Railway by using SERVQUAL model. Pacific Business Review International, 8(2), 82-88. Retrieved from www.pbr.co.in

Kalaiselvi, A., Sandhya, D., \& Athira, C. G. (2017). Passenger satisfaction towards railway with reference to Combatore junction. International Journal of Development Research, 7(10), 1632816330. Retrieved from https://www.journalijdr.com/sites/default/files/issuepdf/10727.pdf

Maruvada, D. P., \& Bellamkonda, R. S. (2010). Analyzing the Passenger Service Quality of the Indian Railways using Railqual: Examining the Applicability of Fuzzy Logic. International Journal of Innovation, Management and Technology, 1(5), 478-482. Retrieved from http://ijimt.org/papers/84-M479.pdf 
The Influence of Service Quality and Price on the Interest of Commuterline KRL Passengers at Tanjung Priok Station Aisyah, Salim, Sofyan

Ojo, T. K., Mireku, D. O., Suleman, D., \& Nutsogbodo, R. Y. (2014). Service quality and customer satisfaction of public transport on Cape Coast-Accra Route, Ghana. Developing Country Studies, 4(18), 142-148.

Rajeswari, V., \& Santa Kumari, K. (2014). Satisfaction and Service Quality in Indian Railways -A Study on Passenger Perspective. IOSR Journal of Economics and Finance, 4(1), 2321-5933. Retrieved from http://www.iosrjournals.org/iosr-jef.html

Semuel, H., \& Wijaya, N. (2010). Service Quality, Perceived value, Satisfaction, Trust, dan Loyalty pada PT. Kereta Api Indonesia Menurut Penilaian Pelanggan Surabaya. Jurnal Manajemen Pemasaran, 4(1), 23-37. Retrieved from http://jurnalpemasaran.petra.ac.id/index.php/mar/article/view/18083/17991

Septianita, Wi., Agus Winarno, W., \& Arif, A. (2014). Pengaruh Kualitas Sistem, Kualitas Informasi, Kualitas Pelayanan Rail Ticketing System (RTS) Terhadap Kepuasan Pengguna. E-Journal Ekonomi Bisnis Dan Akutansi, 1(1), 53-56. https://doi.org/10.19184/ejeba.v1i1.570

Setiawan, E. B. (2015). Analisis Pengaruh Nilai Teknologi Informasi Terhadap Keunggulan Bersaing Perusahaan (Studi Kasus Pemanfaatan E-Tiketing Terhadap Loyalitas Pengguna Jasa Kereta Api). Jurnal Sains, Teknologi Dan Industri, 12(2), 204-211.

Setyo, P. E. (2017). Pengaruh Kualitas produk dan harga terhadap kepuasaan konsumen "Best Autoworks." Jurnal Manajemen, 1(6), 755-764. Retrieved from https://journal.uc.ac.id/index.php/performa/article/view/404/363 